\title{
Pengaruh Pendekatan Pembelajaran Blended Learning Menggunakan Platform Zoom Terhadap Hasil Belajar Peserta Didik Sekolah Menengah Pertama
}

\author{
Yusryanto, ${ }^{1),}$, Salmawati ${ }^{11}$ \\ ${ }^{1)}$ Universitas Lakidende - Unaaha \\ *yus010987@gmail.com
}

Abstrak: Penelitian ini dilatarbelakangi karena permasalahan masih banyaknya pendidik dan peserta didik yang belum memaksimalkan akses internet di era globalisasi saat ini ditambah lagi situasi dan kondisi pada masa covid-19 mengharuskan setiap orang melakukan kegiatan di rumah. Blended learning merupakan cara belajar yang mengkombinasikan antara pembelajaran tatap muka (face to face) dan pembelajaran berbasis komputer (online dan offline). Tujuan penelitian ini adalah mengetahui seberapa besar pengaruh dan perbedaan pendekatan blended learning menggunakan platform zoom terhadap pemahaman konsep siswa pada mata pelajaran Matematika di kelas VII SMP Negeri 1 Andowia. Penelitian ini menggunakan pendekatan kuasi eksperimen melalui nonequivalent control group design. Subjek penelitian adalah siswa kelas VIIA (kelas eksperimen) dan Kelas VIIB (kelas kontrol). Hasil penelitian diperoleh rata-rata skor pre-test siswa kelas eksperimen 67,982\% dan siswa kelas kontrol 60,526\% dari skor ideal. Sedangkan rata-rata skor post-test siswa kelas eksperimen 78,947\% dan rata-rata skor post-test siswa kelas kontrol 69,737\% dari skor ideal. Peningkatan dari persentase rata-rata skor pre-test dan post-test digambarkan oleh persentase rata-rata skor $\mathrm{N}$-gain siswa kelas eksperimen 40,752\% lebih tinggi jika dibandingkan persentase rata-rata skor $\mathrm{N}$-gain siswa kelas kontrol yang hanya 22,613\%. Hal ini menunjukkan bahwa pendekatan blended learning menggunakan platform zoom efektif dan berpengaruh di dalam meningkatkan pemahaman konsep siswa.

Kata Kunci: blended learning, platform zoom, pemahaman konsep.

\section{Pendahuluan}

Perkembangan teknologi komunikasi berdampak pada dunia pendidikan. Pada kenyataan saat ini, jika pendidikan dihubungkan dengan teknologi, maka akan jelas terlihat bahwa pendidikan sangat memerlukan bantuan teknologi. Ditambah lagi wabah pandemi covid-19 telah mengubah kebiasaan-kebiasaan dengan melakukan berbagai protokol kesehatan seperti social distancing, phisycal distancing, cuci tangan, memakai masker. Hal tersebut membuat dunia pendidikan pun mengalami perubahan yang sangat besar, para guru tidak lagi melakukan tugasnya di kelas-kelas pembelajaran melainkan berbasis daring (online). Sehingga, pemanfaatan teknologi dalam dunia pendidikan khususnya dalam sistem pembelajaran telah mengubah sistem pembelajaran konvensional menjadi sistem pembelajaran modern yang berasaskan teknologi informasi dan komunikasi (Information and Communication Technology [ICT]). Diantaranya adalah media komputer, handphone, televisi, konferensi video, dan media elektronik lainnya dengan internetnya yang pada akhirnya memunculkan elektronic learning (e-learning).

Pola pembelajaran e-learning ini dapat dilaksanakan secara tatap muka dengan mediasi komputer, atau pembelajaran yang terdiri dari sebuah kombinasi tatap muka dan format pembelajaran yang dilakukan dengan menggunakan perangkat komputer yang disebut dengan blended learning. Model blended learning ini memungkinkan siswa belajar (paling tidak sebagian) melalui konten dan petunjuk yang disampaikan secara daring (online) dengan kendali mandiri terhadap waktu, tempat, urutan maupun kecepatan belajar dari guru.

Pembelajaran model daring (online) merupakan pemanfaatan jaringan internet oleh guru dan peserta didik dalam proses pembelajaran. Layanan pendidikan dengan daring (online) pada umumnya dilakukan dengan berbagai aplikasi atau platform seperti zoom, google classroom, webex meeting, dan lain-lain. Pemanfaatanya dapat dilakukan sesuai dengan kebutuhan masing-masing dengan tujuan mendistribusikan bahan ajar kepada peserta didik. Aplikasi-aplikasi ini memberikan peluang terhubungnya guru dan peserta didik meskipun secara online. 
Platform zoom adalah model pembelajaran kombinasi yang dikembangkan bertujuan menyederhanakan distribusi pembelajaran. Layanan berbasis internet ini dirancang dengan sistem e-learning bagi para guru dan mampu membagikan materi secara paperless. Dengan memanfaatkan teknologi dalam pembelajaran diharapkan delivery of learning terjamin dengan efektif dikarenakan adanya umpan balik, adanya penggabungan dan pengkolaborasian kegiatan belajar mandiri, serta personalisasi pembelajaran yang berdasarkan kebutuhan siswa menggunakan permainan dan simulasi.

Penggunaan metode blended learning menggunakan platform zoom ini, diharapkan akan mengarahkan siswa untuk menarik minat belajar dan lebih meningkatkan pemahaman siswa terhadap materi-materi yang disampaikan oleh guru ditengah pandemi covid-19 yang belum berakhir dan sebagai solusi masa depan didalam menghadapi era industri 4.0, dimana semua praktisi pendidikan termasuk peserta didik harus mampu menggunakan teknologi sebagai media pembelajaran. Teknologi tidak dapat dipisahkan dari dunia pendidikan, guru dituntut harus memaksimalkan dan terbiasa menggunakan teknologi atau paling tidak dapat mengakses internet dalam pembelajaran daring (online). Oleh sebab itu, berdasarkan pemaparan diatas maka tentunya penelitian ini bertujuan untuk mengetahui seberapa besar pengaruh dan perbedaan pendekatan blended learning menggunakan platform zoom terhadap pemahaman konsep siswa pada mata pelajaran Matematika di kelas VII SMP Negeri 1 Andowia.

\section{Metode}

Jenis penelitian yang digunakan merupakan penelitian eksperimen. Bentuk penelitian yang digunakan dalam penelitian ini adalah eksperimen semu (quasi experimental research). Desain yang digunakan dalam penelitian ini adalah Nonequivalent Control Group Design, dengan pola sebagai berikut (Sugiyono, 2013):

Tabel 1. Desain Penelitian

\begin{tabular}{cccc}
\hline \multirow{2}{*}{ Kelas } & \multicolumn{3}{c}{ Desain Penelitian } \\
\cline { 2 - 4 } & Pretest & Perlakuan & Postest \\
\hline $\mathrm{E}$ & $\mathrm{O}_{1}$ & $\mathrm{X}$ & $\mathrm{O}_{2}$ \\
$\mathrm{~K}$ & $\mathrm{O}_{3}$ & & $\mathrm{O}_{4}$ \\
\hline
\end{tabular}

Keterangan:

$\mathrm{E} \quad=$ Kelas eksperimen

$\mathrm{K} \quad=$ Kelas kontrol

$\mathrm{O}_{1}=$ Pre test pada kelas eksperimen

$\mathrm{O}_{3}=$ Pre test pada kelas kontrol

$\mathrm{X}=$ Perlakuan pada kelas eksperimen menggunakan pendekatan blended learning dengan platform zoom

$\mathrm{O}_{2}=$ Post test pada kelas eksperimen

$\mathrm{O}_{4}=$ Post test pada kelas kontrol

Menurut hubungan antara satu variabel dengan variabel yang lain maka variabel dalam penelitian ini dapat dibedakan menjadi: 1) Variabel independen (bebas) yaitu blended learning dengan platform zoom dan metode konvensional; 2) Variabel dependen (terikat) yaitu pemahaman konsep siswa (Y)

Sampel yang diambil dalam penelitian ini yaitu dengan mengambil 2 kelas, VII A dan B. Satu kelas dijadikan sebagai kelas eksperimen dan satu kelas lagi sebagai kelas kontrol. Dalam penelitian ini peneliti menggunakan teknik pengumpulan data tes tulis (pre test dan post test), angket, observasi dan dokumentasi.

Instrumen penelitian yang digunakan dalam penelitian ini terdiri dari: (1) Seperangkat tes melalui soal yang dibuat dengan berpedoman pada indikator-indikator dari pemahaman konsep yang terdiri dari 10 soal esai yang akan dikerjakan oleh siswa secara invidu. (2) Seperangkat Angket ini digunakan untuk mengetahui seberapa respon siswa terhadap model pembelajaran blended learning dalam pembelajaran matematika.

Langkah-langkah teknik analisis deskriptif yang meliputi: modus, median, mean, varians dan standar deviasi. Kemudian dilakukan uji persyaratan analisis dengan uji homogenitas dan uji normalitas. Untuk menguji hipotesis digunakan statistik parametris dengan uji t-test 
Langkah-langkah yang dilakukan untuk mengolah data hasil pre test dan post test: 1) Menguji normalitas data hasil pre test dan post test pada kelas eksperimen dan kelas kontrol. Untuk menguji kenormalan distribusi pada kelas eksperimen dan kelas kontrol dapat digunakan uji kolmogorov-smirnov; 2) Melakukan uji homogenitas data hasil pre test dan post test dengan tujuan untuk mengetahui kesamaan dua varians antara kelas eksperimen dan kelas control; 4) Melakukan uji perbedaan dua rata-rata (Uji t). Uji t diperlukan untuk mengetahui ada tidaknya perbedaan rata-rata kemampuan siswa dalam matematika antara kelas eksperimen dan kelas control; 5) Penarikan Kesimpulan. Jika $H_{0}$ ditolak maka $H_{1}$ diterima. Jika $H_{1}$ diterima maka akan ada perbedaan yang signifikan antara kelas yang diberi perlakuan dengan kelas yang tidak diberi perlakuan. Apabila terbukti ada perbedaan antara kelas eksperimen dan kelas kontrol maka dilakukan uji satu pihak.

Adapun analisis data nontes berupa data observasi sikap, keterampilan, aktifitas siswa dan angket pada penelitian ini menggunakan teknik analisis data deskriptif. Untuk pernyataan dalam angket yang hanya terdiri dari pernyataan positif. Dalam menganalisis data yang berasal dari angket tersebut dilakukan dengan cara memberikan skor pada setiap jawaban penilaian tersebut dengan Sangat Setuju (SS) $=4$, Setuju $(S)=3$, Tidak Setuju (TS) $=2$, dan Sangat Tidak Setuju (STS) $=1$.

\section{Hasil dan Pembahasan}

Penelitian ini dilakukan dengan tujuan mengetahui seberapa besar pengaruh pendekatan blended learning menggunakan platform zoom terhadap pemahaman konsep siswa pada mata pelajaran Matematika di kelas VII SMP Negeri 1 Andowia, kemudian juga mengetahui perbedaan pemahaman konsep siswa yang menggunakan pendekatan blended learning menggunakan platform zoom (kelas VIIA) dan yang tidak menggunakan pendekatan blended learning menggunakan platform zoom (Kelas VIIB) pada mata pelajaran Matematika di kelas VII SMP Negeri 1 Andowia. Seberapa besar pengaruh pendekatan blended learning menggunakan platform zoom terhadap pemahaman konsep siswa dapat diketahui melalui hasil belajar siswa pada hasil pretest dan posttest di kelas eksperimen. Sedangkan, untuk mengetahui perbedaan pemahaman konsep siswa dapat dilihat dengan membandingkan hasil post test antara kelas VIIA (kelas eksperimen) dan kelas VIIB (kelas kontrol).

Hasil penelitian yang diperoleh dari pelaksanaan pendekatan blended learning menggunakan platform zoom terhadap pemahaman konsep siswa pada mata pelajaran Matematika di Kelas VII SMP Negeri 1 Andowia dikumpulkan dan disajikan melalui skor yang diperoleh dari hasil belajar siswa melalui soal yang dibuat dengan berpedoman pada indikator-indikator dari pemahaman konsep dan juga dilengkapi dengan tanggapan siswa terhadap pelaksanaan model pendekatan tersebut melalui Angket yang diberikan.

Sebelum dilakukan analisis inferensial, terlebih dahulu dianalisis secara deskriptif, yang meliputi modus, median, mean, varians dan standar deviasi. Berikut deskripsi pemahaman konsep siswa kelas kontrol dan siswa kelas eksperimen hasil pre-test, post-test dan $\mathrm{N}$-gain.

Tabel 2. Deskripsi pemahaman konsep siswa kelas kontrol dan siswa kelas eksperimen hasil pre-test, post-test dan N-gain

\begin{tabular}{lcccccc}
\hline \multirow{2}{*}{ Pemahaman Konsep } & \multicolumn{2}{c}{ pre-test } & \multicolumn{2}{c}{ post-test } & \multicolumn{2}{c}{ N-gain } \\
\cline { 2 - 7 } & kelas kont & kelas eks & kelas kont & kelas eks & kelas kont & kelas eks \\
\hline Skor Ideal & 12 & 12 & 12 & 12 & 1 & 1 \\
Skor Maksimum & 10 & 11 & 11 & 12 & 0,5 & 1 \\
Skor Minimum & 4 & 5 & 6 & 6 & 0 & 0 \\
Skor Rerata & 7,263 & 8,158 & 8,368 & 9,474 & 0,226 & 0,408 \\
\% Skor Rerata & 60,526 & 67,982 & 69,737 & 78,947 & 22,613 & 40,752 \\
Simpangan Baku & 1,695 & 1,537 & 1,383 & 1,577 & 0,184 & 0,263 \\
\hline
\end{tabular}

Hasil analisis pemahaman konsep yang tertuang pada diagram dibawah ini memperlihatkan perbandingan persentase skor rata-rata pre-test, post-test dan $\mathrm{N}$-gain pemahaman konsep siswa dan secara jelas dapat dilihat pada Gambar 1.

Pada Gambar 1 terlihat bahwa persentase rata-rata skor pre-test siswa kelas eksperimen sebesar 67,982\% dan siswa kelas kontrol sebesar 60,526\% dari skor ideal. Sedangkan persentase rata-rata skor post-test siswa kelas eksperimen sebesar 78,947\% dan persentase rata-rata skor post-test siswa kelas kontrol 69,737\% dari skor ideal. 
Peningkatan dari persentase rata-rata skor pre-test dan post-test baik pada siswa kelas kontrol maupun pada siswa kelas eksperimen digambarkan oleh persentase rata-rata skor $\mathrm{N}$-gain siswa kelas eksperimen sebesar 40,752\% lebih tinggi jika dibandingkan persentase rata-rata skor N-gain siswa kelas kontrol yang hanya sebesar 22,613\%. Hal ini menunjukkan bahwa pendekatan blended learning menggunakan platform zoom efektif untuk meningkatkan pemahaman konsep siswa.

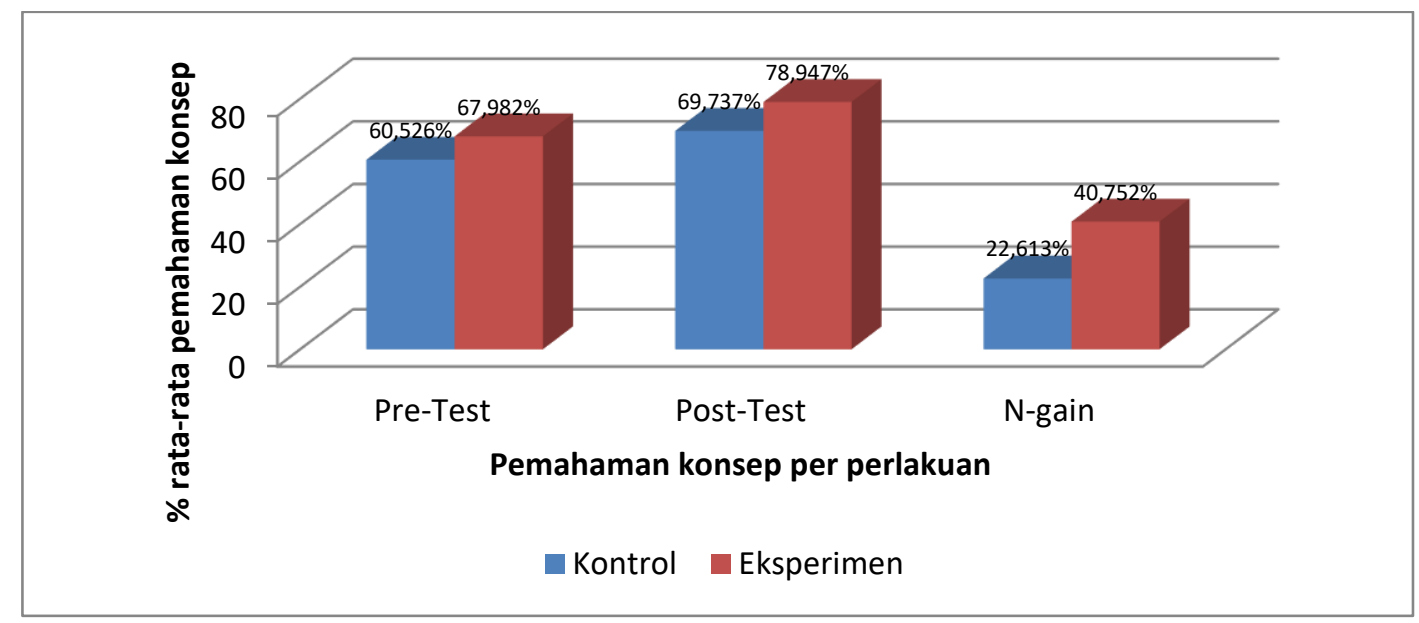

Gambar 1. Diagram pemahaman konsep per perlakuan terhadap persentase rata-rata pemahaman konsep siswa

Selanjutnya dilakukan uji normalitas, uji homogenitas dan uji hipotesis pemahaman konsep siswa pada pre test. Uji normalitas yang dilakukan terhadap pre-test pemahaman konsep untuk siswa kelas eksperimen nilai $\gamma^{2}$.hitung $=0,978$ dan $\gamma^{2}$.tabel $=5,991$, ternyata $\gamma^{2}$.hitung $<\gamma^{2}$.tabel, sedangkan untuk siswa kelompok kontrol diperoleh nilai $\gamma^{2}$.hitung $=2,157$ sehingga $\gamma^{2}{ }_{\text {.hitung }}<\gamma^{2}$.tabel pada tingkat kepercayaan 95\% $(\alpha=0,05)$. Hal ini menunjukkan bahwa data hasil pre-test pemahaman konsep siswa kelas eksperimen dan pre-test pemahaman konsep siswa kelas kontrol berdistribusi normal pada $\alpha=0,05$.

Hasil uji homogenitas pre-test pemahaman konsep siswa kelas eksperimen dan siswa kelas kontrol diperoleh $X^{2}{ }_{\text {.hitung }}<X^{2}{ }_{\text {tabel }}$. Hal ini berarti bahwa distribusi kedua data kelas tersebut adalah homogen pada $\alpha=$ 0,05. Karena kedua kelompok tersebut berdistribusi normal dan homogen, maka pengujian hipotesis dilanjutkan ke uji-t. Hasil uji-t menunjukkan nilai $t_{\text {.hitung }}=1,842$ dan $t_{\text {tabel }}=2,028$. Karena nilai $t_{\text {.hitung }}<t_{\text {tabel, }}$ maka dapat disimpulkan bahwa kedua kelompok tersebut memiliki kemampuan pemahaman konsep awal yang sama.

Hasil uji normalitas, homogenitas dan uji hipotesis data pre-test pemahaman konsep siswa kelas eksperimen dan siswa kelas kontrol menggunakan program excel dapat dilihat pada Tabel berikut.

Tabel 3. Rangkuman hasil uji normalitas, uji homogenitas dan uji-t pre-test pemahaman konsep siswa

\begin{tabular}{|c|c|c|c|c|c|c|}
\hline \multirow{3}{*}{ Kelas } & \multicolumn{6}{|c|}{ Uji Statistik } \\
\hline & \multicolumn{2}{|c|}{ Normalitas (Chi Square) } & \multicolumn{2}{|c|}{ Homogenitas (Uji Bartlet) } & \multicolumn{2}{|c|}{ Uji-t } \\
\hline & $\gamma^{2} \cdot$ Hitung & $\gamma^{2} \cdot$ Tabel & $X^{2} \cdot$ Hitung & $\chi^{2} \cdot$ Tabel & t. Hitung & t. Tabel \\
\hline $\begin{array}{l}\text { Eksperimen } \\
\text { Kontrol }\end{array}$ & $\begin{array}{l}0,978 \\
2,157\end{array}$ & 5,991 & 0,174 & 3,841 & 1,842 & 2,028 \\
\hline Keterangan & \multicolumn{2}{|c|}{$\begin{array}{c}\text { Distribusi normal } \\
(\text { pada } \alpha=0,05 ; \mathrm{dk}=2)\end{array}$} & \multicolumn{2}{|c|}{$\begin{array}{c}\text { Homogen } \\
(\text { pada } \alpha=0,05 ; \mathrm{dk}=1)\end{array}$} & \multicolumn{2}{|c|}{$\begin{array}{c}\text { Terima } H_{o} \\
\text { (pada } \alpha=0,05 ; \mathrm{dk}=36)\end{array}$} \\
\hline
\end{tabular}

Dari Tabel 3 terlihat bahwa hasil uji homogenitas pre-test pemahaman konsep siswa kelas eksperimen dan siswa kelas kontrol diperoleh $\chi^{2}{ }_{\text {.hitung }}<X^{2}{ }_{\text {tabel }}$. Hal ini berarti bahwa distribusi kedua data kelas tersebut adalah homogen pada $\alpha=0,05$. Karena kedua kelompok tersebut berdistribusi normal dan homogen, maka pengujian hipotesis dilanjutkan ke uji-t. Hasil uji-t menunjukkan nilai $t_{\text {.hitung }}=1,842$ dan $t_{\text {tabel }}=2,028$. Karena nilai $t_{\text {.hitung }}$ $<\mathrm{t}_{\text {.tabel, }}$ maka dapat disimpulkan bahwa kedua kelompok tersebut memiliki kemampuan pemahaman konsep awal yang sama.

Selanjutnya dilakukan analisa untuk post-test pemahaman konsep siswa. Berdasarkan hasil uji normalitas distribusi data post-test pemahaman konsep pada Tabel 4 untuk siswa kelas eksperimen diperoleh nilai $\gamma^{2}$.hitung $=$ 
0,269. Sedangkan untuk kelompok siswa kelas kontrol diperoleh nilai $\gamma^{2} \cdot$.hitung $=0,850$ dengan $\gamma^{2}{ }_{\text {tabel }}=5,991$ sehingga $\gamma^{2}$.hitung $<\gamma^{2}$.tabel. Hal ini menunjukkan bahwa data hasil post-test pemahaman konsep siswa kelas eksperimen dan post-test pemahaman konsep siswa kelas kontrol berdistribusi normal pada $\alpha=0,05$. Hasil analisis post-test pemahaman konsep siswa ditampilkan pada Tabel 4 berikut.

Tabel 4. Rangkuman hasil uji normalitas, uji homogenitas dan uji-t post-test pemahaman konsep siswa

\begin{tabular}{|c|c|c|c|c|c|c|}
\hline \multirow{3}{*}{ Kelas } & \multicolumn{6}{|c|}{ Uji Statistik } \\
\hline & \multicolumn{2}{|c|}{ Normalitas (Chi Square) } & \multicolumn{2}{|c|}{ Homogenitas (Uji Bartlet) } & \multicolumn{2}{|c|}{ Uji-t } \\
\hline & $\gamma^{2} \cdot$ Hitung & $\gamma^{2} \cdot$ Tabel & $X^{2} \cdot$ Hitung & $X^{2} \cdot$ Tabel & $\mathrm{t}_{\text {Hitung }}$ & t. Tabel \\
\hline $\begin{array}{l}\text { Eksperimen } \\
\text { Kontro }\end{array}$ & 0,269 & 5,991 & 0,315 & 3,841 & 2,990 & 2,028 \\
\hline Keterangan & $\begin{array}{r}\text { Distril } \\
\text { (pada } \alpha=\end{array}$ & $\begin{array}{l}\text { ormal } \\
; \mathrm{dk}=2)\end{array}$ & $\begin{array}{r}H \\
\text { (pada } \alpha \\
\end{array}$ & $\begin{array}{l}\mathrm{n} \\
\mathrm{dk}=1)\end{array}$ & $\begin{array}{r}\text { Te } \\
\text { (pada } \alpha=\end{array}$ & $\begin{array}{l}\mathrm{H}_{\mathrm{a}} \\
\mathrm{dk}=36)\end{array}$ \\
\hline
\end{tabular}

Hasil uji homogenitas pre-test pemahaman konsep siswa kelas eksperimen dan kelas kontrol diperoleh $X^{2}{ }_{\text {.hitung }}<X^{2}{ }_{\text {.tabel }}$. Hal ini berarti bahwa distribusi data kedua kelas tersebut adalah homogen pada $\alpha=0,05$. Karena kedua kelompok tersebut berdistribusi normal dan homogen, maka uji hipotesis dilanjutkan ke uji-t. Hasil uji-t menunjukkan nilai $t_{\text {.hitung }}=2,990$ dan $t_{\text {tabel }}=2,028$ sehingga nilai $t_{\text {.hitung }}>t_{\text {tabel. }}$. Hal ini berarti bahwa skor ratarata pemahaman konsep siswa kelas eksperimen secara signifikan lebih tinggi dari siswa kelas kontrol. Dengan kata lain pemahaman konsep siswa yang mendapat pembelajaran dengan pendekatan blended learning menggunakan platform zoom lebih baik dibandingkan dengan pemahaman konsep siswa yang tidak menggunakan pendekatan blended learning menggunakan platform zoom.

Selanjutnya untuk mengetahui perbedaan pemahaman siswa dengan pendekatan blended learning menggunakan platform zoom (kelas VIIA) dan yang tidak dengan pendekatan blended learning menggunakan platform zoom (Kelas VIIB) pada mata pelajaran Matematika di kelas VII SMP Negeri 1 Andowia dapat dilihat melalui perbandingan peningkatan pemahaman konsep antara siswa kelas eksperimen dan siswa kelas kontrol, dapat diketahui dengan melakukan analisis terhadap data $\mathrm{N}$-gain, yang meliputi uji normalitas, uji homogenitas dan uji-t. Hasil analisis uji normalitas, uji homogenitas dan uji-t dapat dilihat pada tabel 5 berikut.

Tabel 5. Rangkuman hasil uji normalitas, uji homogenitas dan uji-t N-gain pemahaman konsep siswa

\begin{tabular}{|c|c|c|c|c|c|c|}
\hline \multirow{3}{*}{ Kelas } & \multicolumn{6}{|c|}{ Uji Statistik } \\
\hline & \multicolumn{2}{|c|}{ Normalitas (Chi Square) } & \multicolumn{2}{|c|}{ Homogenitas (Uji Bartlet) } & \multicolumn{2}{|c|}{ Uji-t } \\
\hline & $\gamma^{2} \cdot$ Hitung & $\gamma^{2} \cdot$ Tabel & $\chi^{2} \cdot$ Hitung & $\chi^{2} \cdot$ Tabel & t.Hitung & t. Tabel \\
\hline Eksperimen & 3,162 & \multirow{2}{*}{5,991} & \multirow{2}{*}{1,859} & \multirow{2}{*}{3,841} & \multirow{2}{*}{2,244} & \multirow{2}{*}{2,028} \\
\hline Kontrol & 5,049 & & & & & \\
\hline Keterangan & \multicolumn{2}{|c|}{$\begin{array}{c}\text { Distribusi normal } \\
(\text { pada } \alpha=0,05 ; \mathrm{dk}=2)\end{array}$} & \multicolumn{2}{|c|}{$\begin{array}{c}\text { Homogen } \\
(\text { pada } \alpha=0,05 ; \mathrm{dk}=1)\end{array}$} & \multicolumn{2}{|c|}{$\begin{array}{c}\text { Terima } H_{a} \\
(\text { pada } \alpha=0,05 ; d k=36)\end{array}$} \\
\hline
\end{tabular}

Berdasarkan Tabel 5, menunjukkan bahwa hasil uji $\mathrm{N}$-gain untuk siswa kelas eksperimen diperoleh $\gamma^{2} \cdot$.hitung $=3,162$ dengan $\gamma^{2}$.tabel $=5,991$ sehingga $\gamma^{2}$.hitung $<\gamma^{2}$.tabel. Hal ini memberikan indikasi bahwa data $\mathrm{N}$-gain siswa kelas eksperimen berdistribusi normal. Demikian juga pada siswa kelas kontrol diperoleh $\quad \gamma^{2}$.hitung $=5,049$ dengan $\gamma^{2}$.tabel yang sama, sehingga $\gamma^{2}$.hitung $<\gamma^{2}$.tabel. Hal ini menunjukkan bahwa data $\mathrm{N}$-gain siswa kelas kontrol juga berdistribusi normal pada $\alpha=0,05$.

Hasil analisis terhadap homogenitas $\mathrm{N}$-gain pemahaman konsep siswa kelas eksperimen dan siswa kelas kontrol terlihat bahwa $X^{2}{ }_{\text {.hitung }}=1,859$ dan $X^{2}{ }_{\text {tabel }}=3,841$, sehingga $X^{2}{ }_{\text {.hitung }}<X^{2}{ }_{\text {tabel }}$. Hal ini menunjukkan bahwa distribusi data kedua kelas tersebut adalah homogen pada $\alpha=0,05$. Kedua kelompok kelas pembelajaran tersebut berdistribusi normal dan homogen, sehingga uji hipotesis dilanjutkan ke uji-t.

Berdasarkan hasil uji-t, N-gain pemahaman konsep siswa kelas eksperimen dan siswa kelas kontrol diperoleh bahwa $t_{\text {.hitung }}=2,244$ dan $t_{\text {tabel }}=2,028$ sehingga $t_{\text {.hitung }}>t_{\text {.tabel. }}$. Kondisi ini menggambarkan bahwa peningkatan pemahaman konsep siswa kelas eksperimen berbeda nyata dengan siswa kelas kontrol pada tingkat kepercayaan 95\% $(\alpha=0,05)$ sehingga dapat dikatakan bahwa peningkatan pemahaman konsep siswa kelas eksperimen lebih tinggi dibandingkan dengan peningkatan pemahaman konsep siswa kelas kontrol. Dengan 
demikian pembelajaran dengan pendekatan blended learning menggunakan platform zoom secara signifikan dapat lebih meningkatkan pemahaman konsep siswa dibanding dengan siswa yang tidak menggunakan pendekatan blended learning.

Dari uraian diatas menunjukkan bahwa pembelajaran dengan pendekatan blended learning menggunakan platform zoom mampu mempengaruhi pemahaman konsep siswa. Pemahaman konsep yang dimaksud dalam penelitian ini adalah dihubungkan dengan hasil belajar siswa, dimana menurut (Nastiti \& Syaifudin, 2020) hubungan tersebut sangatlah rasional karena matematika merupakan pelajaran yang membutuhkan pemahaman konsep yang baik, hal tersebut dikarenakan konsep matematika adalah saling berkaitan. Lebih lanjut (Nastiti \& Syaifudin, 2020) menyampaikan bahwa pengaruh pemahaman konsep dengan hasil belajar sangat signifikan dan sangat normal dikarenakan untuk dapat menyelesaikan soal-soal matematika perlu adanya pemahaman yang baik mengenai konsep matematika tersebut, sehingga siswa dapat menyelesaikan soal-soal yang diberikan dengan baik. Sehingga dalam penelitian ini juga pemahaman konsep yang dimaksud adalah skor yang diperoleh dari hasil belajar siswa melalui soal yang dibuat dengan berpedoman pada indikator-indikator dari pemahaman konsep.

Dalam penelitian yang dilakukan oleh (M et al., 2016) menyimpulkan bahwa model pembelajaran blended learning berpengaruh positif dan signifikan terhadap hasil belajar siswa. (Husamah, 2013) menyampaikan bahwa pembelajaran blended learning dapat meningkatkan keaktifan, sikap kemandirian belajar, dan hasil belajar peserta didik dalam pembelajaran, sementara menurut (Yendri \& Kom, 2011), bila blended learning dilakukan dengan baik, maka paling tidak ada tiga manfaat yang dapat diperoleh salah satunya meningkatkan hasil pembelajaran melalui pendidikan jarak jauh, sementara itu, (Khaerunnisa, 2020) dalam kesimpulannya menyampaikan bahwa blended learning yang dilakukan mampu menjadi jalan keluar dari persoalan pelaksanaan pendidikan jarak jauh.

Lebih lanjut (Sandiwarno, 2016) menyatakan bahwa pembelajaran melalui aplikasi zoom cloud meeting selain dapat mengoptimalkan adanya interaksi secara langsung antara siswa dan pendidik, juga dapat menampilkan materi pembelajaran di tampilan dan dapat dilihat oleh semua partisipan, sehingga partisipan tidak hanya mendengar penjelasan melainkan dapat juga mencermati materi yang diberikan.

Dalam penelitian ini juga, siswa diberikan angket untuk mengetahui seberapa besar antusias dan respon siswa terhadap pendekatan pembelajaran dengan blended learning melalui platform zoom. Angket yang diberikan berisi 15 butir pertanyaan yang terbagi atas tiga aspek penilaian dengan rentang skor 1-5. Rentang skor yang dipilih dengan ketentuan skor 1 untuk jawaban sangat tidak setuju dan skor 5 untuk jawaban sangat setuju, siswa kemudian diminta memberikan checklist terhadap pertanyaan di dalam angket tersebut.

Berdasarkan data dari aspek kegunaan blended learning melalui platform zoom sebagai media pendukung pembelajaran yang diperoleh bahwa $72 \%$ siswa mengatakan bahwa blended learning melalui platform zoom sangat mendukung content pembelajaran dan dapat membuat koneksi antara guru dan siswa. Sebanyak $67 \%$ siswa juga menilai bahwa blended learning melalui platform zoom sangat mudah digunakan dan memiliki sifat yang interaktif. Hal ini juga sejalan dengan apa yang disampaikan oleh (Wihartini, 2019) bahwa model blended learning menjadi salah satu model yang menarik bagi siswa karena pembelajaran tidak hanya dapat dilakukan dengan tatap muka saja, dengan menggunakan model blended learning siswa juga dapat mencari informasi sebanyak-banyaknya melalui bantuan internet. Lebih lanjut disimpulkan bahwa model pembelajaran blended learning dapat digunakan dalam proses pembelajaran untuk meningkatkan hasil belajar siswa, meningkatkan motivasi belajar siswa dan menumbuhkan kemampuan brpikir kritis pada diri siswa. Berdasarkan hal ini, maka dapat disimpulkan bahwa kegunaan blended learning melalui platform zoom sebagai media pembelajaran siswa memiliki kriteria baik.

Namun demikian, sekitar 16\% siswa mengatakan bahwa kegunaan blended learning melalui platform zoom sebagai media pembelajaran siswa kurang baik. Hal ini terjadi karena blended learning melalui platform zoom adalah hal baru bagi siswa, mereka kurang terbiasa menggunakan media pembelajaran berbasis internet dan perangkat komputer atau gadget/handphone. Dengan demikian dapat disimpulkan bahwa blended learning melalui platform zoom memiliki kegunaan yang baik dalam mendukung kegiatan pembelajaran dengan persentase rata-rata $88 \%$.

Berdasarkan aspek kinerja dengan blended learning melalui platform zoom sebagai Media Pembelajaran dapat dikatakan bahwa 70\% siswa mengatakan kinerja blended learning melalui platform zoom sebagai media pembelajaran mempunyai kriteria sangat baik. Sebanyak $81 \%$ siswa menilai blended learning melalui platform 
zoom memiliki kriteria kejelasan materi yang sangat baik, dimana siswa dapat menemukan dan menyerap banyak informasi didalamnya. Berdasarkan uraian diatas dapat disimpulkan bahwa kinerja blended learning melalui platform zoom sebagai media pembelajaran memiliki kriteria baik dengan rata-rata $88 \%$.

Namun demikian, dari aspek kinerja walaupun secara kolektif baik tetapi didapatkan rata-rata hanya $47 \%$ siswa yang mengatakan bahwa mereka nyaman menggunakan blended learning melalui platform zoom dalam kegiatan pembelajaran, sisanya merasa tidak nyaman. Salah satu penyebab ketidaknyaman tersebut diantaranya fasilitas belajar. Sejalan yang diungkapkan oleh (Limon, 2016) bahwa fasilitas yang kurang memadai akan mengganggu proses dan hasil belajar peserta didik. Menurut (Rohmah, 2015) menyatakan bahwa hasil belajar dipengaruhi oleh faktor yang berasal dari dalam atau internal dan faktor yang berasal dari luar atau eksternal. Salah satu faktor internal diantaranya adalah kurangnya fasilitas internet dan jaringan internet akan membuat kemajuan belajar siswa menjadi terhambat. Sedangkan menurut (Ekawardhana, 2020) menyampaikan bahwa memang kelebihan zoom adalah menyediakan banyak fitur yang sangat bermanfaat dalam virtual class, namun kelemahannya dengan menggunakan media video conference zoom, pendidik mengalami kesusahan dalam memperhatikan peserta didik karena pada saat menggunakan share screen tool, pada layar hanya memunculkan video dari beberapa peserta didik saja. Selain itu, untuk zoom yang regular hanya memiliki waktu 40 menit saja, sehingga kalau materi pembelajaran belum selesai dijelaskan, pendidik harus mengundang ulang peserta didik untuk masuk ke dalam room.

Selanjutnya, berdasarkan aspek efektivitas blended learning melalui platform zoom dapat dikatakan bahwa sebanyak $72 \%$ siswa berpendapat bahwa blended learning melalui platform zoom dapat dijadikan media belajar yang menyenangkan karena dapat menggali informasi sebanyak-banyaknya didalam proses pembelajaran. Selain itu 63\% siswa mengatakan bahwa blended learning melalui platform zoom dapat membantu menyerap materi pembelajaran yang disampaikan karena lebih real time. Kesimpulannya adalah blended learning melalui platform zoom sangat efektif digunakan sebagai media pembelajaran dengan persentase rata-rata $87 \%$.

Pembelajaran dengan blended learning melalui platform zoom pada penelitian ini berdasarkan analisis pretest dan posttest sangat berpengaruh, selanjutnya berdasarkan angket dari respon siswa, pembelajaran dengan blended learning melalui platform zoom dapat mendukung pembelajaran jarak jauh, memudahkan siswa untuk menyerap materi pembelajaran yang disampaikan pendidik karena lebih real timed an interaktif sebagai media pembelajaran. Konsep blended learning melalui platform zoom memungkinkan untuk adanya interaksi secara langsung antar siswa dan guru, namun tidak pada tempat yang sama. Menurut (Pregot, 2013) menyampaikan bahwa ketika seorang pengajar mengupayakan dan mengintegrasikan blended learning dengan prinsip-prinsip pengajaran yang selaras dengan kebutuhan siswa, maka hasil belajar siswa akan sama atau bahkan lebih efektif bagi sebagian besar siswa jika dibandingkan dengan pembelajaran di dalam kelas melalui tatap muka.

Pembelajaran menggunakan blended learning melalui platform zoom seperti di dalam kelas, dan dapat membantu siswa dan guru untuk beradaptasi melakukan pembelajaran jarak jauh. Pembelajaran dengan menggunakan blended learning melalui platform zoom membantu guru menilai perkembangan dan keaktifan siswa secara langsung, dapat menjadi sarana sebagai tempat belajar jarak jauh untuk siswa, memberikan peluang bagi siswa untuk berpartisipasi dalam proses pembelajaran, dan dapat memberikan retensi bagi anak didik. Menurut (Sugandi, 2018), Pembelajaran berbasis blended learning memberikan hasil yang positif terhadap peningkatan hasil dan motivasi belajar matematika siswa. Selain itu, pembelajaran berbasis blended learning juga dimungkinkan untuk dilakukan pada pembelajaran matematika mengingat generasi digital merupakan generasi yang terbiasa dengan teknologi digital sehingga akan lebih mudah dalam penerapannya. Dengan demikian, pembelajaran blended learning dapat dijadikan solusi oleh seorang pendidik dalam mengajarkan matematika bagi generasi digital karena mampu meningkatkan motivasi dan hasil belajar mereka. Dengan hasil belajar siswa yang meningkat maka itu berarti mereka memiliki pemahaman yang baik mengenai konsep matematika yang telah dipelajarinya.

\section{Simpulan}

Hasil penelitian menunjukkan bahwa pendekatan blended learning menggunakan platform zoom efektif dan berpengaruh di dalam meningkatkan pemahaman konsep siswa. Dalam penelitian ini juga, siswa diberikan angket untuk mengetahui seberapa besar antusias dan respon siswa terhadap pendekatan pembelajaran dengan blended learning melalui platform zoom. Dari aspek kegunaan blended learning melalui platform zoom sebagai media 
pendukung pembelajaran yang diperoleh bahwa $72 \%$ siswa mengatakan bahwa blended learning melalui platform zoom sangat mendukung content pembelajaran dan dapat membuat koneksi antara guru dan siswa. Dari aspek kinerja dengan blended learning melalui platform zoom sebagai Media Pembelajaran dapat dikatakan bahwa 70\% siswa mengatakan kinerja blended learning melalui platform zoom sebagai media pembelajaran mempunyai kriteria sangat baik, sementara dari aspek efektivitas blended learning melalui platform zoom dapat dikatakan bahwa sebanyak $72 \%$ siswa berpendapat bahwa blended learning melalui platform zoom dapat dijadikan media belajar yang menyenangkan karena dapat menggali informasi sebanyak-banyaknya didalam proses pembelajaran.

\section{Ucapan Terima Kasih}

Puji syukur penulit panjatkan kepada Allah SWT yang telah memberikan rahmat serta karunia, sehingga penulis akhirnya dapat menyelesaikan penelitian ini tepat waktu. Kami menyadari bahwa tanpa bantuan dari berbagai pihak maka sesungguhnya penelitian ini tidak akan berjalan dengan sebaik-baiknya. Oleh karena itu, kami sangat berterima kasih yang tak terhingga kepada semua pihak yang telah ikut membantu dan mensupport sehingga penelitian ini dapat terselesaikan dengan baik.

\section{Daftar Pustaka}

Ekawardhana, N. E. (2020). Efektivitas Pembelajaran dengan Menggunakan Media Video Conference. Seminar Nasional Dan Ilmu Terapan (SNITER) IV, Vol 4 No 1 (2020): Seminar Nasional Ilmu Terapan (SNITER) 2020, A-9-1-A-9-7. https://ojs.widyakartika.ac.id/index.php/sniter/article/view/218

Husamah. (2013). Pembelajaran Bauran (blended learning). In Prestasi Pustaka Publisher. Prestasi Pustaka Publisher. http://research-report.umm.ac.id/index.php/research-report/article/view/1171

Khaerunnisa, F. (2020). Evaluasi Penerapan Blended Learning Pada Pembelajaran Bahasa Arab di SMPIT Ibadurrahman: Studi Kasus Di Kelas VII Akhwat. ALSUNIYAT: Jurnal Penelitian Bahasa, Sastra, Dan Budaya Arab, 2(2), 95-108. https://doi.org/10.17509/alsuniyat.v2i2.24808

Limon, M. R. (2016). The Effect of the Adequacy of School Facilities on StudentsâđI Performance and Achievement in Technology and Livelihood Education. International Journal of Academic Research in Progressive Education and Development, 5(1), 45-58. https://doi.org/10.6007/ijarped/v5-i1/2060

M, A. G., Suryaningtiyas, W., \& Kristanti, F. (2016). Penggunaan Model Pembelajaran Blended Learning terhadap Hasil Belajar Matematika Kelas VIII di SMPN 38 Surabaya. MUST: Journal of Mathematics Education, Science and Technology, 1(1), 10. https://doi.org/10.30651/must.v1i1.97

Nastiti, F. F., \& Syaifudin, A. H. (2020). Hubungan Pemahaman Konsep Matematis Terhadap Hasil Belajar Siswa Kelas VIII SMP N 1 Plosoklaten Pada Materi Lingkaran. PHI: Jurnal Pendidikan Matematika, 4(1), 8. https://doi.org/10.33087/phi.v4i1.80

Pregot, M. V. (2013). The Case for Blended Instruction: Is It a Proven Better Way to Teach? US-China Education Review A, 3(5), 320-324. https://acces.bibl.ulaval.ca/login?url=http://search.ebscohost.com/login.aspx?direct=true\&db=eric\&AN $=$ ED543176\&lang $=$ fr\&site $=$ ehost-live

Rohmah, N. (2015). Psikologi Pendidikan. https://books.google.co.id/books/about/PSIKOLOGI_PENDIDIKAN.html?id=Lq11zQEACAAJ\& redir esc $=$ y

Sandiwarno, S. (2016). Perancangan Model E-Learning Berbasis Collaborative Video Conference Learning Guna Mendapatkan Hasil Pembelajaran Yang Efektif Dan Efisien. Jurnal Ilmiah FIFO, 8(2), 191. https://doi.org/10.22441/fifo.v8i2.1314

Sugandi, E. (2018). Blended Learning Sebagai Solusi Pembelajaran Matematika Bagi Generasi Digital. National Conference on Mathematics, Science and Education (NACOMSE), 1(01), 225-234. http://proceeding.uim.ac.id/index.php/nacomse/article/view/164

Wihartini, K. (2019). Analisis Manfaat Penggunaan Model Pembelajaran Blended Learning Dalam Proses 
Pembelajaran. Prosiding Seminar Nasional Fakultas Ilmu Sosial Universitas Negeri Medan, 3, 1001-1003. http://digilib.unimed.ac.id/id/eprint/37313

Yendri, D., \& Kom, M. (2011). Blended Learning : Model Pembelajaran Kombinasi E-Learning Dalam Pendidikan Jarak Jauh. c. https://adoc.pub/blended-learning-model-pembelajaran-kombinasi-e-learning-dal.html 